\title{
Identification of Lactobacilli and Bifidobacteria
}

\author{
Gerald W. Tannock \\ Department of Microbiology, University of Otago, \\ PO Box 56, Dunedin, New Zealand
}

\begin{abstract}
Selective culture media and phenotypic tests enable lactobacilli to be differentiated from morphologically similar bacteria. The accurate identification of Lactobacillus species can be accomplished by reference to $16 \mathrm{~S}$ rRNA gene sequences. Species-specific, PCR primers that target the 16S-23S rRNA spacer region are available for a limited number of Lactobacillus species. Molecular methods for the comprehensive identification of Bifidobacterium species are not yet available. Only DNA-DNA reassociation provides a reliable means of species identification for this genus at present. Bifidobacteria can be differentiated from morphologically similar bacteria by the use of genus-specific, PCR primers or oligonucleotide probes.
\end{abstract}

\section{Introduction}

Marked changes have occurred in bacterial classification since the application of molecular technologies to this task. The impetus for major change has resulted from the observation that $16 \mathrm{~S}$ ribosomal RNA (rRNA) sequences can be used as evolutionary chronometers (40). Some regions of the $16 \mathrm{~S}$ rRNA molecule are conserved throughout all bacterial species and can be used to align sequences obtained from different isolates. Alignment of these conserved regions permits comparison of the remaining regions (Figure 1, V 1 to V9) which are variable as to nucleotide base sequence between many species $(6,33,36)$. From a practical point of view, the 16S rRNA gene sequences (rDNA) can be used in the reliable identification of many bacterial species through the derivation of specific oligonucleotide probes or polymerase chain reaction (PCR) based techniques $(19,36,38,39)$. Other regions of the genome also offer opportunities as targets for identification procedures (10). These molecular approaches allow Lactobacillus species to be reliably identified, but much developmental work remains to be accomplished in the case of the bifidobacteria.

\section{Identification by Phenotype}

Traditionally, lactobacillus and bifidobacterial species have been identified on the basis of cell morphology, analysis of fermentation products and associated enzyme activities, and the ability to utilise various carbohydrate substrates. The application of these approaches in the classification and identification of Lactic Acid Bacteria has been the subject of several reviews and will not be covered in this article (11, $28,32,43)$. Suffice it to say that, in general, phenotypic methods suffer from a lack of reproducibility generated by conditions of culture related to different laboratories, and to the diversity of strains (biotypes) that comprise the recognised species $(1,11$, 


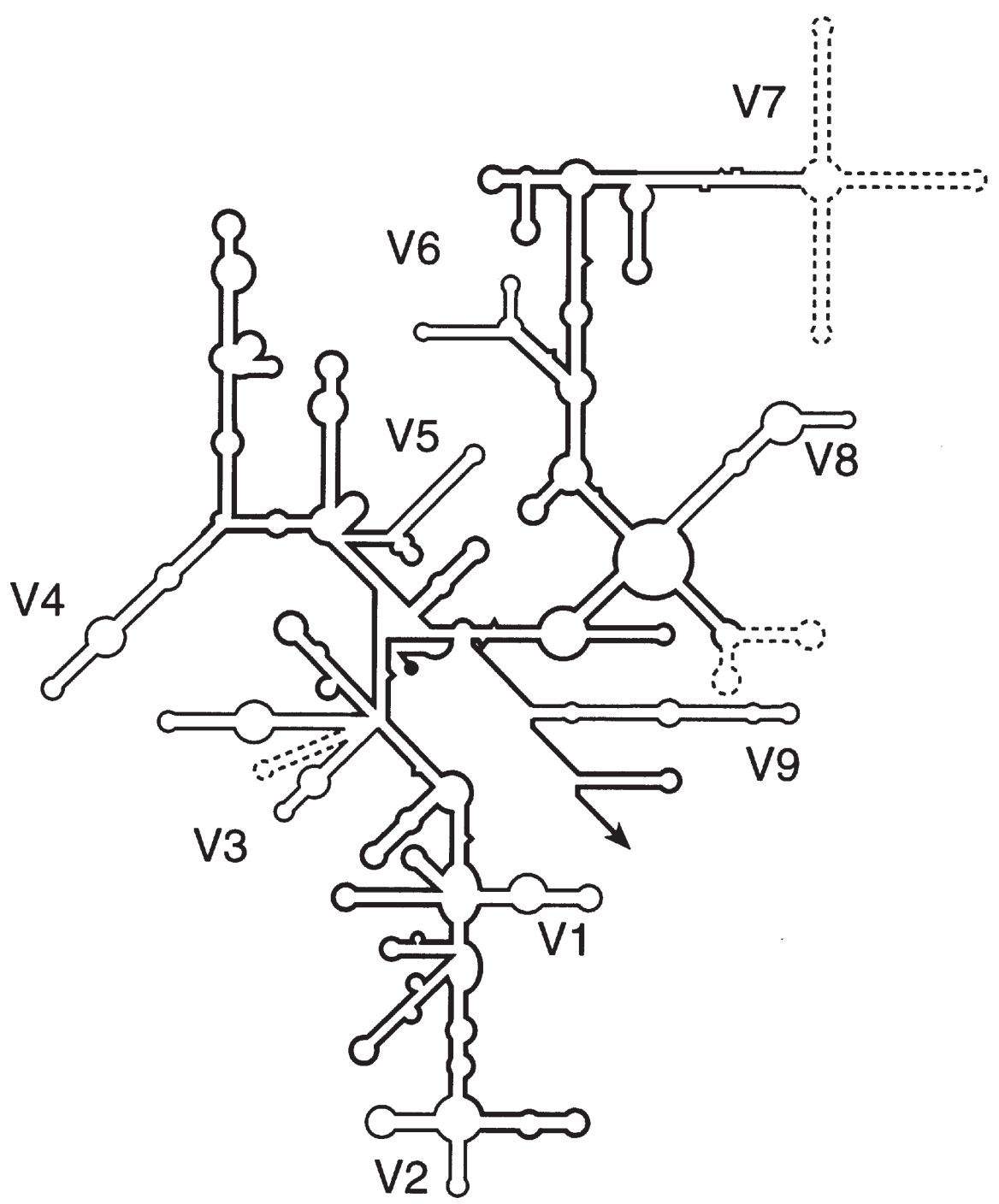

Figure 1. Secondary structure model for prokaryotic 16S rRNA. Regions where the nucleotide base sequence is most variable are labelled V1 to V9. After Neefs and colleagues (26).

32). Nucleic acids are universal in cellular biology, and the nucleotide base sequence of these molecules is not influenced by culture conditions. Analysis of nucleic acids thus provides a basis for identification methods that are reproducible from one laboratory to another. Genotypic approaches hold the most promise for the rapid and accurate identification of lactobacilli and bifidobacteria. 
Table 1. Lactobacillus species

\begin{tabular}{|c|c|}
\hline L. acetotolerans & L. acidophilus \\
\hline L. agilis & L. alimentarius \\
\hline L. amylolyticus & L. amylophilus \\
\hline L. amylovorus & L. animalis \\
\hline L. aviarius subsp. araffinosus & L. aviarius subsp. aviarius \\
\hline L. bifermentans & L. brevis \\
\hline L. buchneri & L. carnis \\
\hline L. casei & L. catenaforme \\
\hline L. cellobiosus & L. collinoides \\
\hline L. coryniformis subsp. coryniformis & L. coryniformis subsp. torquens \\
\hline L. crispatus & L. curvatus subsp. curvatus \\
\hline L. curvatus subsp. melibiosus & L. delbrueckii subsp. bulgaricus \\
\hline L. delbrueckii subsp. delbrueckii & L. delbrueckii subsp. lactis \\
\hline L. farciminis & L. fermentum \\
\hline L. fructivorans & L. fructosus \\
\hline L. gallinarum & L. gasseri \\
\hline L. graminis & L. hamsteri \\
\hline L. helveticus & L. hilgardii \\
\hline L. homohiochii & L. iners \\
\hline L. intestinalis & L. jensenii \\
\hline L. johnsonii & L. kandleri \\
\hline L. kefiranofaciens & L. kefirgranum \\
\hline L. kefiri & L. kunkeei \\
\hline L. lindneri & L. malefermentans \\
\hline L. mali & L. maltaromicus \\
\hline L. manihotivorans & L. murinus \\
\hline L. oris & L. panis \\
\hline L. parabuchneri & L. paracasei subsp. paracasei \\
\hline L. paracasei subsp. tolerans & L. parakefiri \\
\hline L. paraplantarum & L. pentosus \\
\hline L. plantarum & L. pontis \\
\hline L. reuteri & L. rhamnosus \\
\hline L. rogosae & L. ruminis \\
\hline L. sakei subsp. carnosus & L. sakei subsp. sakei \\
\hline L. salivarius subsp. salicinius & L. salivarius subsp. salivarius \\
\hline L. sanfranciscensis & L. sharpeae \\
\hline L. suebicus & L. uli \\
\hline L. vaccinostercus & L. vaginalis \\
\hline L. vitulinus & L. zeae \\
\hline
\end{tabular}

For further information, see reference 36.

\section{Lactobacilli}

\section{Genus Identification}

Members of the genus Lactobacillus can be selected on solid culture media that have an acidic $\mathrm{pH}$ (e.g. Rogosa SL agar). While many Lactobacillus strains used in the dairy industry can be cultured under microaerophilic, or even aerobic conditions, intestinal isolates proliferate best under anaerobic conditions. Lactobacilli are grampositive, non-spore-forming rods (ranging from coccobacilli to long, slender bacilli). Confirmation that the isolates belong to the genus Lactobacillus can be accomplished by testing for the absence of catalase activity, and the presence of lactic acid as the major acid produced from the fermentation of glucose. Acetic, succinic and formic acids may be detected in minor quantities in some cultures (16). Assignment of lactobacillus isolates to homofermentative or heterofermentative categories (by simply observing, by means of a Durham tube, whether gas is produced from glucose) is also a useful phenotypic test. Genus-specific primers for PCR-based identification have not been described. 


\section{Species Identification}

The taxonomy of the lactobacilli has been subject to flux during recent years, but there are currently 70 species (Table 1). From the point of view of probiotics research, however, 19 species are currently of most interest (Table 2).

Table 2. Lactobacillus Species Detected in the Intestinal Tract and/or used in Probiotic Products

\begin{tabular}{lll}
\hline L. acidophilus & L. crispatus & L. hamsteri \\
L. agilis & L. delbrueckii subsp. bulgaricus & L. intestinalis \\
L. aviarius & L. gallinarum & L. plantarum \\
L. amylovorus & L. gasseri & L. rhamnosus \\
L. brevis & L. johnsonii & L. reuteri \\
L. casei & L. murinus & L. ruminis \\
& & L. salivarius \\
\hline
\end{tabular}

For further information, see references 9 and 11.

Comparison of $16 \mathrm{~S}$ rDNA gene sequences from lactobacilli shows that the V1, V2 and V3 regions contain the species-specific information. Therefore, for identification purposes, amplification by PCR and sequencing of less than half of the gene (less than $750 \mathrm{bp}$ ) may be sufficient, but whole gene sequencing is still best for establishing phylogenetic relationships. 16S rDNA sequence homology of less than $97.0 \%$, it has been observed, means that the bacteria being compared will usually have less than 60-70\% DNA similarity over the whole chromosome (DNA-DNA reassociation; the "gold standard" for species delineation) and hence are unlikely to belong to the same species (34).

$16 \mathrm{~S}, 23 \mathrm{~S}$ and $5 \mathrm{~S}$ rRNA genes are arranged within an operon on the bacterial chromosome (Figure 2). Nucleotide base sequence information has become available for the region between the $16 \mathrm{~S}$ and $23 \mathrm{~S}$ genes: the $16 \mathrm{~S}-23 \mathrm{~S}$ spacer region. Many bacteria have multiple copies (alleles) of the rRNA operon per genome and the spacer region may vary in size within different operons. This relates to the number and type of tRNA genes (tRNAglu, tRNAile, tRNAala) located in some spacer regions. PCR primers that anneal to conserved regions of the $16 \mathrm{~S}$ and $23 \mathrm{~S}$ rRNA genes permit the amplification of the spacer regions (10). Often, "short" (absence of tRNA genes) and "long" (presence of one or two tRNA genes) spacer regions are detected, and these can be purified from agarose gels for subsequent sequencing. The nucleotide sequence of the spacer regions of several Lactobacillus species has been determined. These sequences show that the spacer region is hypervariable, and species-specific PCR primers, based on these regions, have been derived for the identification of lactobacilli of interest to the food industry $(5,25,35)$.

Oligonucleotide probes based on the analysis of hypervariable domains in nucleic acid molecules have been derived for identification purposes (31). These include a number that are reported to be specific for Lactobacillus species (Table 3 ). It should be noted, however, that consistent, specific, results are sometimes difficult to achieve when using oligonucleotide probes: control of the temperature and ionic strength of the washing solution are critical for obtaining optimal results.

\section{Bifidobacteria}

\section{Genus Identification}

Several solid media have been devised for the selective cultivation of members of the genus Bifidobacterium. Antibiotics or acidic additives have been popular choices in conferring selective properties on the media (4). Few of these media are completely selective for bifidobacteria, however, although Beerens agar and Rogosa SL agar (incubated for three days) have proved useful in the author's laboratory (23). 
Identification of Lactobacilli and Bifidobacteria 57

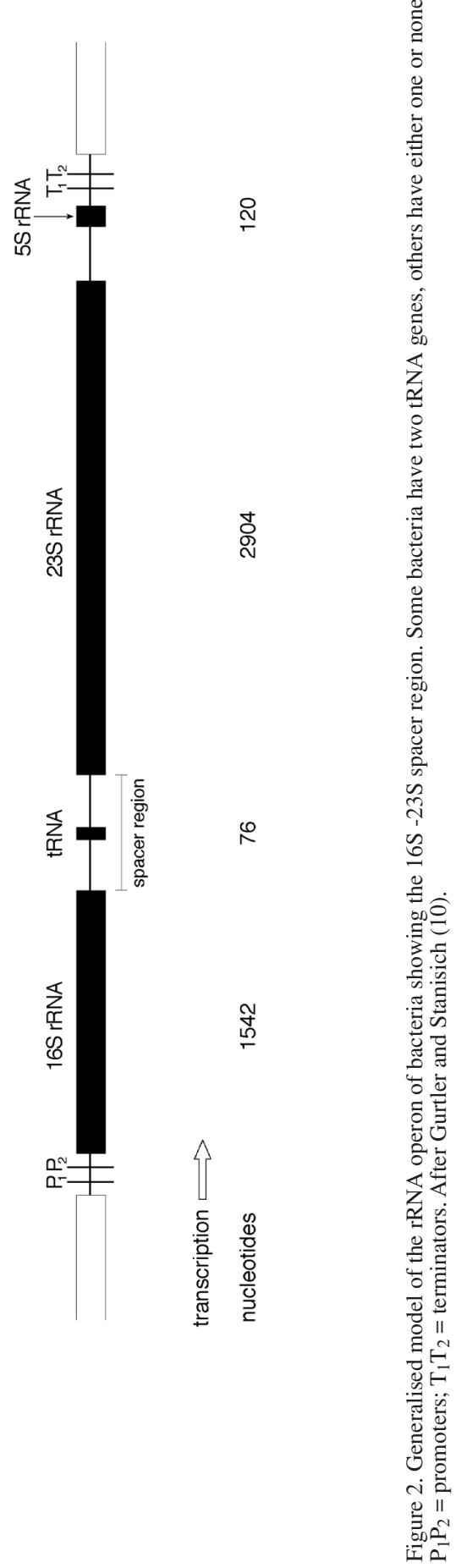


Table 3. Examples of rRNA-targeted Oligonucleotide Probes that Detect Lactobacillus Species

\begin{tabular}{lcc}
\hline \multicolumn{1}{c}{ Species } & Target & Reference \\
\hline L. acidophilus & $23 \mathrm{~S}$ & 28 \\
L. amylovorus & $16 \mathrm{~S}$ & 7 \\
L. brevis & $16 \mathrm{~S}$ & 37 \\
L. curvatus & $23 \mathrm{~S}$ & 13 \\
L. collinoides & $16 \mathrm{~S}$ & 7 \\
L. delbrueckii & $23 \mathrm{~S}$ & 14 \\
L. fermentum & $16 \mathrm{~S}$ & 37 \\
L.gasseri & $23 \mathrm{~S}$ & 28 \\
L. helveticus & $23 \mathrm{~S}$ & 14 \\
L. hilgardii & $16 \mathrm{~S}$ & 7 \\
L. johnsonii & $23 \mathrm{~S}$ & 28 \\
L. kefir & $16 \mathrm{~S}$ & 7 \\
L. kefiranofaciens & $23 \mathrm{~S}$ & 7 \\
L. paracasei & $23 \mathrm{~S}$ & 14 \\
L. parabuchneri & $23 \mathrm{~S}$ & 7 \\
L. pontis & $16 \mathrm{~S}$ & 37 \\
L. reuteri & $16 \mathrm{~S}$ & 7 \\
L. ruminis & $16 \mathrm{~S}$ & 12 \\
L. sake & $16 \mathrm{~S}$ & 13 \\
L. sanfrancisco & $16 \mathrm{~S}$ & 37 \\
\hline
\end{tabular}

Bifidobacteria are gram-positive pleomorphic rods, ranging from uniform to branched, bifurcated $\mathrm{Y}$ and $\mathrm{V}$ forms, spatulate or club shaped. They are strictly anaerobic (although some strains can tolerate oxygen in the presence of carbon dioxide), non-motile and non-spore-forming. The branching nature of bifidobacteria is not only strain dependent but also depends on the medium used for cultivation. Comparison of cell morphology of bifidobacterial isolates grown on a standard medium can aid in identification (29). Cell morphology alone, however, must be supplemented with the results of biochemical tests to differentiate bifidobacteria from morphologically similar genera (Lactobacillus, Actinomyces, Propionibacterium, Eubacterium).

Bifidobacteria ferment hexoses by a fructose-6-phosphate phosphoketolase (F6PPK) shunt and are the only intestinal bacteria known to utilise this fermentation pathway. It is often termed the "bifidus pathway" $(4,29)$. F6PPK catalyses the splitting of fructose-6-phosphate to erythrose-4-phosphate and acetyl-phosphate. Demonstration of F6PPK activity in cellular extracts has been a useful method for differentiating bifidobacteria from morphologically similar bacteria (Figure 3 ).

Fermentation of glucose by the bifidus pathway produces acetic and lactic acids in a theoretical ratio of 3:2 (in reality, this is sometimes exceeded). Gas liquid chromatography of fermentation products thus provides another reliable means of differentiating bifidobacteria from other bacterial types $(4,29)$.

Biochemical tests for the identification of members of the genus Bifidobacterium are now largely superseded by the use of the genus-specific PCR primers described by Kok and colleagues (18) or Kaufman and colleagues (17). These primers amplify a $523 \mathrm{bp}$ or $1.35 \mathrm{kbp}$ region, respectively, of the $16 \mathrm{~S}$ rRNA gene (Table 4). Genus-specific probes, Bif164 and Im3, have proved useful in the enumeration of total populations of bifidobacteria in faecal and food samples, respectively $(17,19)$.

\section{Species Identification}

There are 32 species of bifidobacteria (Table 5). They can sometimes be differentiated, with great difficulty, using the results of fermentation tests together with observations of cell morphology and the electrophoretic mobilities of enzymes such as transaldolase (14 types) or 6-phopshogluconate dehydrogenase (19 types; 32). 
Reagents

(1) $\quad 0.05 \mathrm{M}$ sodium phosphate buffer ( $\mathrm{pH} 6.5$ ) containing $500 \mathrm{mg}$ L-cysteine per litre.

(2) Sodium fluoride $(6 \mathrm{mg} / \mathrm{ml})$ and potassium or sodium iodoacetic acid $(10 \mathrm{mg} / \mathrm{ml})$.

(3) Hydoxylamine hydrochloride $(13.9 \mathrm{gm} / 100 \mathrm{ml})$ adjusted to $\mathrm{pH} 6.5$ with sodium hydroxide before use.

(4) Trichloroacetic acid (15\% weight/volume).

(5) $4 \mathrm{M}$ hydrochloric acid.

(6) Ferric chloride (FeCl.6H2O; $5 \%$ weight/volume in $0.1 \mathrm{M}$ hydrochloric acid).

(7) Fructose-6-phosphate (sodium salt; $70 \%$ purity; $80 \mathrm{mg} / \mathrm{ml}$ ).

(8) TPY broth (grams per litre; see reference 29): trypticase 10.0 ; phytone 5.0 ; glucose 5.0 ; yeast extract 2.5 ; tween $801.0 \mathrm{ml}$; cysteind hydrochloride 0.5 ; dipotassium monohydrogen phosphate 2.0 ; magnesium chloride 0.5 ; zinc sulphate 0.25 ; calcium chloride 0.15 ; ferric chloride $0.03 ; \mathrm{pH} 6.5$.

Test

Harvest cells by centrifugation from a 24-hour culture in TPY broth. Wash the bacterial cells in $10 \mathrm{ml}$ of $0.05 \mathrm{M}$ phosphate buffer. Suspend the cells in one $\mathrm{ml}$ of phosphate buffer in a microfuge tube.

Centrifuge to deposit the cells, then remove supernatant and add $45 \mu \mathrm{l}$ of mutanolyisn solution $(1 \mathrm{mg} / \mathrm{ml}), 250$ ul of lyosozyme solution $(6 \mathrm{mg} / \mathrm{ml})$ and $650 \mu$ of phosphate buffer. Suspend the cells. Disrupt the cells by sonication, keeping the preparations on ice.

Transfer $50 \mu \mathrm{l}$ aliquots of the sonicated material to three wells of a microtitire plate. Add $12 \mu \mathrm{l}$ of the sodium fluoride-iodoacetic acid solution to each well. Then add $12 \mu \mathrm{l}$ of fructose-6phosphate to two of the wells (test) but not to the third well which serves as a negative control. Incubate the plate at $37^{\circ} \mathrm{C}$ for 30 minutes. Stop the reaction by adding $75 \mu$ of hydroxylamine solution to each well and leave at room temperature for 10 minutes. Then add $50 \mu$ of trichloroacetic acid solution and $50 \mu \mathrm{l}$ of $4 \mathrm{M}$ hyrdrochloric acid. Add $50 \mu \mathrm{l}$ of ferric chloride solution. A reddish-violet colour indicates fructose-6-phosphate phosphoketolase activity.

Figure 3. Fructose-6-phosphate phosphoketolase test for bifidobacteria. J. P. Burton, Department of Microbiology, University of Otago, after Scardovi (29).

The V1, V2 and V3 regions of the 16S rDNA sequences from 24 bifidobacterial species compared by McCartney (22) appeared to provide the best opportunity for the differentiation of species. Comparison of 16S rDNA sequences from 18 bifidobacterial species by Leblond-Bourget and colleagues (20), however, showed that they ranged in similarity from 92 to $99 \%$. This high level of relatedness makes it impossible to differentiate between some bifidobacterial species on the basis of $16 \mathrm{~S}$ rDNA sequence analysis (8).

Sequences (274 to 552 bp in length) obtained by PCR amplification of $16 \mathrm{~S}$ $23 \mathrm{~S}$ spacer regions of 18 bifidobacterial species gave similar phylogenetic information to that provided by $16 \mathrm{~S}$ rDNA (20). The spacer region sequences were more variable, however, and Leblond-Bourget and colleagues have suggested that they provide a means of distinguishing between bifidobacterial strains (20). The spacer regions do not appear, therefore, to contain useful information that could be used in rapid tests to differentiate bifidobacterial species.

Only moderate progress has been made in the derivation of species-specific oligonucleotide probes for bifidobacteria (Table 4). Yamamoto and colleagues (42) derived probes 16 to 19 nucleotides in length that targeted 16S rRNA sequences. Probes specific for Bifidobacterium adolescentis, Bifidobacterium bifidum, Bifidobacterium breve, Bifidobacterium infantis, and Bifidobacterium longum were demonstrated using crude high-molecular-weight RNA preparations. The B. bifidum and $B$. infantis probes were not specific when tested using whole bacterial cells that had been fixed with formaldehyde. Mangin et al., (21) reported that randomly-cloned fragments of chromosomal DNA could be used to differentiate $B$. adolescentis, $B$. longum, B. bifidum and Bifidobacterium animalis. Similarly, a randomly-cloned DNA fragment specific for $B$. breve has been reported by Ito and colleagues (15). 
Table 4. Oligonucleotide Primers and Probes Described for use in the Identification or Detection of Bifidobacteria

\begin{tabular}{|c|c|c|c|}
\hline Oligonucleotide & Specificity/Target & Application & Reference \\
\hline Bif164 & $\begin{array}{l}\text { Genus/16S rRNA } \\
\text { enumeration }\end{array}$ & Probe, detection, & 19 \\
\hline Bif164/Bif662 & $\begin{array}{l}\text { Genus/16S rDNA } \\
\text { identification }\end{array}$ & PCR, detection, & 19 \\
\hline $\operatorname{lm} 3$ & $\begin{array}{l}\text { Genus/16S rRNA } \\
\text { enumeration }\end{array}$ & Probe, detection, & 17 \\
\hline $\operatorname{lm} 3 / \operatorname{lm} 26$ & $\begin{array}{l}\text { Genus/16S rDNA } \\
\text { identification }\end{array}$ & PCR, detection, & 17 \\
\hline A6/17 & B. adolescentis/unspecified & Identification & 21 \\
\hline PAD & $\begin{array}{l}\text { B.adolescentis/16S rRNA } \\
\text { identification }\end{array}$ & Probe, detection, & 42 \\
\hline an1 & B. animalis/unspecified & Identification & 21 \\
\hline $\mathrm{bA} 7 / 2$ & B. bifidum/unspecified & Identification & 21 \\
\hline BB22 & B. breve/unspecified & Identification & 15 \\
\hline PBR & $\begin{array}{l}\text { B. breve/ } 16 \mathrm{~S} \text { rRNA } \\
\text { identification }\end{array}$ & Probe, detection, & 42 \\
\hline PLO & $\begin{array}{l}\text { B. longum/16S rRNA } \\
\text { identification }\end{array}$ & Probe, detection, & 42 \\
\hline L6/45 & B. longum/phage integrase & Identification & 21 \\
\hline
\end{tabular}

It is clear, therefore, that rapid methods for the accurate and comprehensive identification of bifidobacterial species remain elusive. Considerable developmental work is required in this area since DNA-DNA reassociation is currently the only reliable method of Bifidobacterium species identification $(1,41)$.

\section{Identification of Bacterial Species in Relation to Probiotic Research and Development}

The prevalence of lactobacillus and bifidobacterial species in the intestinal tract of humans is not known accurately. Comprehensive studies of the species composing the human intestinal microflora have seldom been attempted, and those that have were conducted prior to the introduction of genotypic methods for the classification of bacteria (1). Probably the best comparisons available of Lactobacillus and Bifidobacterium species present in human faeces are those reported by Mitsuoka (24) and by Biavati and colleagues $(2,3)$. Mitsuoka listed Lactobacillus crispatus, Lactobacillus gasseri, Lactobacillus salivarius, and Lactobacillus reuteri as the major species of the Lactobacillus microflora. Lactobacillus johnsonii, Lactobacillus ruminis, Lactobacillus casei, and Lactobacillus brevis were detected occasionally. Among the bifidobacteria, Bifidobacterium longum predominated in adult humans, while Bifidobacterium bifidum was detected occasionally. In contrast, Bifidobacterium infantis and Bifidobacterium breve were the most prevalent species in infant faeces, with $B$. longum and B. bifidum detected occasionally. The identity of the isolates was determined by phenotypic characterisation, and determination of the mole $\% \mathrm{G}+\mathrm{C}$ of genomic DNA in the case of the lactobacilli. Biavati et al., (2), 
Table 5. Bifidobacterium Species

\begin{tabular}{ll}
\hline B. adolescentis* & B. angulatum* \\
B. animalis & B. asteroides \\
B. bifidum* & B. boum \\
B. breve* & B. catenulatum* \\
B. choerinum & B. coryneforme \\
B. cuniculi & B. dentium* \\
B. gallicum* & B. gallinarum \\
B. globosum* & B. indicum \\
B. infantis* & B. inopinatum \\
B. lactis & B. longum* \\
B. magnum & B. merycicum \\
B. minimum & B.pseudocatenulatum* \\
B. pseudolongum subsp. globosum & B.pseudolongum subsp. pseudolongum \\
B. pullorum & B. ruminantium \\
B. saeculare & B. subtile \\
B. suis & B.thermophilum \\
\end{tabular}

*Detected in human faeces. For further information, see reference 32.

using DNA-DNA reassociation as the primary method of identification, detected $B$. infantis, $B$. breve, and $B$. longum commonly in the faeces of human infants. Bifidobacterium bifidum, $B$. pseudocatenulatum, $B$. dentium, and $B$. catenulatum were isolated less frequently. In the case of samples from adults, $B$. adolescentis, $B$. bifidum, B. catenulatum, B. longum, and B. pseudocatenulatum were detected (3). Differentiation between species, in this latter study, was limited to the use of polyacrylamide gel electrohoresis of soluble cellular proteins.

Comprehensive studies utilising molecular approaches to identify the species commonly present in the intestine of humans inhabiting various geographic regions of the world should be initiated. Probiotics contain species of bifidobacteria and/or lactobacilli that are intended to generate an impact on the intestinal microflora (43, 44). It seems logical that the prevalence of the different species in various countries should be known, preferably before the consumption of probiotics becomes even more widespread. As part of the "environmental impact" report that should be completed for each probiotic that is consumed long term (44), an accurate assessment of the alterations, in terms of species, to the lactobacillus or bifidobacterial microfloras should be included. Some probiotics have been retailed in particular countries for many years. Lactobacillus rhamnosus GG, for example, has been marketed extensively to the general population as a component of milk and other food products in Finland. Has the Lactobacillus microflora of Finns altered dramatically since marketing of these products began? What changes have occurred in the proportions of Lactobacillus species detected in faeces since the introduction of probiotic products? What is the long term effect of any such change on the human population?

Accurate identification of strains of lactobacilli and bifidobacteria must also be accomplished so that consumers can be reliably informed of the content of probiotic products. Many probiotic yogurts are labelled as containing Lactobacillus acidophilus. The re-classification of the "acidophilus" group may mean that some products are currently mislabelled (11). Perhaps "Acidophilus" will be used in future more as a generic marketing term recognised by the consumer, but not necessarily indicative of the microbial content. From the point of view of health regulatory agencies, however, labelling of products should reflect exactly the species composition. 


\section{Future Research}

Major emphasis should be placed on the development of rapid and accurate methods for the identification of Bifidobacterium species. DNA sequences other than those of $16 \mathrm{~S}$ rRNA genes will probably provide the basis of these methods. Comprehensive studies to detect the prevalence of Lactobacillus and Bifidobacterium species in the intestinal microflora of humans should be initiated once satisfactory identification methods are established. Companies that sell cultures to the dairy industry and other probiotic manufacturers must ensure that the strains in their culture collections are identified by genotypic procedures, and that they use current nomenclature.

\section{References}

1. Ballongue, J. 1993. Bifidobacteria and probiotic action, p. 357-428. In S. Salminen and A. von Wright (ed.), Lactic acid bacteria. Marcel Dekker Inc., New York.

2. Biavati, B., P. Castagnoli, F. Crociani, and L. D. Trovatelli. 1984. Species of the Bifidobacterium in the feces of infants. Microbiologica 7: 341-345.

3. Biavati, B., P. Castagnoli, and L. D. Trovatelli. 1986. Species of the genus Bifidobacterium in the feces of human adults. Microbiologica 9: 39-45.

4. Biavati, B., B. Sgorbati, and V. Scardovi. 1992. The genus Bifidobacterium, p. 816-833. In A. Balows, H. G. Truper, M. Dworkin, W. Harder, and K-H. Schleifer (ed.), The prokaryotes, 2nd edition. A handbook on the biology of bacteria: Ecophysiology, isolation, identification, applications (Volume 1). Springer-Verlag, New York.

5. Berthier, F. and S. D. Ehrlich. 1998. Rapid species identification within two groups of closely related lactobacilli using PCR primers that target the 16S/ 23S rRNA spacer region. FEMS Microbiol. Lett. 161: 97-106.

6. Collins, M. D., U. Rodrigues, C. Ash, M. Aguirre, J. A. E. Farrow, A. MartinezMurcia, B. A. Phillips, A. M. Williams, and S. Wallbanks. 1991. Phylogenetic analysis of the genus Lactobacillus and related lactic acid bacteria as determined by reverse transcriptase sequencing of $16 \mathrm{~S}$ rRNA. FEMS Microbiol. Lett. 77: 5-12.

7. Ehrmann, M., W. Ludwig, and K. H. Schleifer. 1994. Reverse dot blot hybridization: A useful method for the direct identification of lactic acid bacteria in fermented food. FEMS Microbiol. Lett. 117: 143-150.

8. Frothingham, R., A. J. Duncan, and K. H. Wilson. 1993. Ribosomal DNA sequences of bifidobacteria: Implications for sequence-based identification of the human colonic flora. Microb. Ecol. Health Dis. 6: 23-27.

9. Goldin, B. and S. L. Gorbach. 1992. Probiotics for humans, p. 355-376. In R. Fuller (ed.), Probiotics. The scientific basis. Chapman and Hall, London.

10. Gurtler, V. and V. A. Stanisich. 1996. New approaches to typing and identification of bacteria using the $16 \mathrm{~S}-23 \mathrm{~S}$ rDNA spacer region. Microbiol. 142: 3-16.

11. Hammes, W. P. and R. F. Vogel. 1995. The genus Lactobacillus, p. 19-54. In: B. J. B. Wood and W. H. Holzapfel (ed.), The lactic acid bacteria. Volume 2. The genera of lactic acid bacteria. Blackie Academic and Professional, London.

12. Hensiek, R., G. Krupp, and E. Stackebrandt. 1992. Development of diagnostic oligonucleotide probes for four Lactobacillus species occurring in the intestinal tract. System. Appl. Microbiol. 15: 123-128.

13. Hertel, C., W. Ludwig, M. Obst, R. F. Vogel, W. P. Hammes, and K-H. Schleifer. 1991. 23S rRNA-targeted oligonucleotide probes for the rapid identification of meat lactobacilli. System. Appl. Microbiol. 14: 173-177.

14. Hertel, C., W. Ludwig, B. Pot, K. Kersters, and K-H. Schleifer. 1993. Differentiation of lactobacilli occurring in fermented milk products by using 
oligonucleotide probes and electrophoretic protein profiles. Syst. Appl. Microbiol. 16: 463-467.

15. Ito, M., T. Ohno, and R. Tanaka. 1992. A specific DNA probe for identification of Bifidobacterium breve. Microb. Ecol. Hlth. Dis. 5: 185-192.

16. Kandler, O. and N. Weiss. 1986. Genus Lactobacillus Beijerinck 1901, 212AL, p. 1209-1234. In P. H. A. Sneath, N. S. Mair, M. E. Sharpe, and J. G. Holt (ed.), Bergey's manual of systematic bacteriology (volume 2). Williams and Wilkins, Baltimore.

17. Kaufmann, P., A. Pfefferkorn, M. Teuber, and L. Meile. 1997. Identification and quantification of Bifidobacterium species isolated from food with genusspecific 16S rRNA-targeted probes by colony hybridization and PCR. Appl. Environ. Microbiol. 63: 1268-1273.

18. Kok, R. G., A. de Waal, F. Schut, G. W. Welling, G. Weenk, and K. J. Hellingwerf. 1996. Specific detection and analysis of a probiotic Bifidobacterium strain in infant faeces. Appl. Environ. Microbiol. 62: 36683672.

19. Langendijk, P. S., F Schuts, G. J. Jansen, G. C. Raangs, G. R. Kamphuis, M. H. F. Wilkinson, and G. J. Welling. 1995. Quantitative fluorescence in situ hybridization of Bifidobacterium spp. with genus-specific 16S rRNA-targeted probes and its application in fecal samples. Appl. Environ. Microbiol. 61: 3069-3075.

20. Leblond-Bourget, N., H. Philippe, I. Mangin, and B. Decaris. 1996. 16S rRNA and $16 \mathrm{~S}$ to $23 \mathrm{~S}$ internal transcribed spacer analyses reveal inter- and intraspecific Bifidobacterium phylogeny. Int. J. System. Bacteriol. 46:102111.

21. Mangin, I., N. Bourget, J-M. Simonet, and B. Decaris. 1995. Selection of species-specific DNA probes which detect strain restriction polymorphism in four Bifidobacterium species. Res. Microbiol. 146: 59-71.

22. McCartney, A. L. 1996. PhD thesis, Department of Microbiology, University of Otago, Dunedin, New Zealand. An investigation of the composition of the human intestinal microflora, particularly the Bifidobacterium and Lactobacillus populations, using ribotyping.

23. McCartney, A. L., W. Wang, and G. W. Tannock. 1996. Molecular analysis of the composition of the bifidobacterial and lactobacillus microflora of humans. Appl. Environ. Microbiol. 62: 4608-4613.

24. Mitsuoka, T. 1992. The human gastrointestinal tract, p. 69-114. In B. J. B. Wood (ed.), The lactic acid bacteria. Volume 1. The lactic acid bacteria in health and disease. Elsevier Applied Science, London.

25. Nakagawa, T., M. Shimada, H. Mukai, K. Asada, I. Kado, K. Fujino, and T. Sato. 1994. Detection of alcohol-tolerant Hiochi bacteria by PCR. Appl. Environ. Microbiol. 60: 637-640.

26. Neefs, J-M., Y. van de Peer, P. de Rijk, S. Chapelle, and R. de Wachter. 1993. Compilation of small ribosomal subunit RNA sequences. Nucleic Acids Res. 21: 3025-3049.

27. Pot, B., C. Hertel, W. Ludwig, P. Descheemaeker, K. Kersters, and K-H. Schleifer. 1993. Identification and classification of Lactobacillus acidophilus, L. gasseri and L. johnsonii strains by SDS-PAGE and rRNA-targeted oligonucleotide probe hybridization. J. Gen. Microbiol. 139: 513-517.

28. Pot, B., W. Ludwig, K. Kersters, and K-H Schleifer. 1994. Taxonomy of lactic acid bacteria, p. 13-90. In: L. de Vuyst and E. J. Vandamme (ed.), Bacteriocins of lactic acid bacteria. Microbiology, genetics and applications. Blackie Academic and Professional, London.

29. Scardovi, V. 1986. Genus Bifidobacterium Orla-Jensen 1924, 472AL, p. 14181434. In P. H. A. Sneath, N. S. Mair, M. E. Sharpe, and J. G. Holt (ed.), Bergey's manual of systematic bacteriology (volume 2). Williams and Wilkins, 
Baltimore.

30. Scardovi, V., L. D. Trovatelli, G. Zani, F. Crociani, and D. Matteuzzi. 1971. Deoxyribonucleic acid homology relationships among species of the genus Bifidobacterium. Int. J. System. Bacteriol. 21: 276-294.

31. Schleifer, K-H., M. Ehrmann, C. Beimfohr, E. Brockmann, W. Ludwig, and R. Amann. 1995. Application of molecular methods for the classification and identification of lactic acid bacteria. Int. Dairy J. 5:1081-1094.

32. Sgorbati, B., B. Biavati, and D. Palenzona. 1995. The genus Bifidobacterium, p. 279-306. In: B. J. B. Wood and W. H. Holzapfel (ed.), The lactic acid bacteria. Volume 2. The genera of lactic acid bacteria. Blackie Academic and Professional, London.

33. Stackebrandt, E. and F. A. Rainey. 1995. Partial and complete 16S rDNA sequences, their use in generation of $16 \mathrm{~S}$ rDNA phylogenetic trees and their implications in molecular ecological studies, p. 1-17. In: A. D. L. Akkeramns, J. D. van Elsas, and F. J. de Bruijn (ed.), Molecular microbial ecology manual. Kluwer Academic Publishers, Dordrecht.

34. Stackebrandt, E., and B. M. Goebel. 1994. Taxonomic note: A place for DNADNA reassociation and $16 \mathrm{~S}$ rRNA sequence analysis in the present species definition in bacteriology. Int. J. System. Bacteriol. 44: 846-849.

35. Tilsala-Timisjarvi, A. and T. Alatossava. 1997. Development of oligonucleotide primers from the 16S-23S rRNA intergenic sequences for identifying different dairy and probiotic lactic acid bacteria by PCR. Int. J. Food Microbiol. 35:4956.

36. Vandamme, P., B. Pot, M. Gillis, P. de Vos, K. Kersters, and J. Swings. 1996 Polyphasic taxonomy, a consensus approach to bacterial systematics. Microb. Rev. 60: 407-438.

37. Vogel, R. F., G. Bocker, P. Stolz, M. Ehrmann, D. Fanta, W. Ludwig, B. Pot, K. Kersters, K. H. Schleifer, and W. P. Hammes. 1994. Identification of lactobacilli from sourdough and description of Lactobacillus pontis sp. nov. Int. J. System. Bacteriol. 44: 223-229.

38. Wang, R-F, W-W. Cao, and C. E. Cerniglia. 1996. PCR detection and quantitation of predominant anaerobic bacteria in human and animal fecal samples. Appl. Environ. Microbiol. 62:1242-1247.

39. Welling, G. W., P. Elfferich, G. C. Raangs, A. C. M. Wildeboer-Veloo, G. J Jansen, and J. E. Degener. 1997. 16S ribosomal RNA-targeted oligonucleotide probes for monitoring of intestinal tract bacteria. Scand. J. Gastroenterol. 32 Supplement 222: 17-19.

40. Woese, C. R. 1987. Bacterial evolution. Microbiol. Rev. 51: 221-271.

41. Yaeshima, T., S. Takahashi, N. Ishibashi, and S. Shimamura. 1996. Identification of bifidobacteria from dairy products and evaluation of a microplate hybridization method. Int. J. Food Microbiol. 30: 303-313.

42. Yamamoto, T., M. Morotomi, and R. Tanaka. 1992. Species-specific oligonucleotide probes for five Bifidobacterium species detected in human intestinal microflora. Appl. Environ. Microbiol. 58: 4076-4079.

43. Tannock, G.W. 1999. Probiotics: A Critical Review. Horizon Scientific Press, Wymondham, U.K.

44. Tannock, G.W. 1999. A fresh look at the intestinal microflora. In: Probiotics: A Critical Review. G.W. Tannock, ed. Horizon Scientific Press, Wymondham, U.K. p. 5-14. 


\section{Further Reading}

Caister Academic Press is a leading academic publisher of advanced texts in microbiology, molecular biology and medical research. Full details of all our publications at caister.com

- MALDI-TOF Mass Spectrometry in Microbiology Edited by: M Kostrzewa, S Schubert (2016) www.caister.com/malditof

- Aspergillus and Penicillium in the Post-genomic Era Edited by: RP Vries, IB Gelber, MR Andersen (2016) www.caister.com/aspergillus2

- The Bacteriocins: Current Knowledge and Future Prospects Edited by: RL Dorit, SM Roy, MA Riley (2016)

www.caister.com/bacteriocins

- Omics in Plant Disease Resistance Edited by: V Bhadauria (2016) www.caister.com/opd

- Acidophiles: Life in Extremely Acidic Environments Edited by: R Quatrini, DB Johnson (2016) www.caister.com/acidophiles

- Climate Change and Microbial Ecology: Current Research and Future Trend

Edited by: J Marxsen (2016)

www.caister.com/climate

- Biofilms in Bioremediation: Current Research and Emerging Technologies

Edited by: G Lear (2016)

www.caister.com/biorem

- Microalgae: Current Research and Applications Edited by: MN Tsaloglou (2016) www.caister.com/microalgae

- Gas Plasma Sterilization in Microbiology: Theory, Applications, Pitfalls and New Perspectives Edited by: H Shintani, A Sakudo (2016) www.caister.com/gasplasma

- Virus Evolution: Current Research and Future Directions Edited by: SC Weaver, M Denison, M Roossinck, et al. (2016) www.caister.com/virusevol

- Arboviruses: Molecular Biology, Evolution and Control Edited by: N Vasilakis, DJ Gubler (2016) www.caister.com/arbo

- Shigella: Molecular and Cellular Biology Edited by: WD Picking, WL Picking (2016) www.caister.com/shigella

-Aquatic Biofilms: Ecology, Water Quality and Wastewater Treatment

Edited by: AM Romaní, H Guasch, MD Balaguer (2016)

www.caister.com/aquaticbiofilms

- Alphaviruses: Current Biology

Edited by: S Mahalingam, L Herrero, B Herring (2016)

www.caister.com/alpha

- Thermophilic Microorganisms

Edited by: F Li (2015)

www.caister.com/thermophile
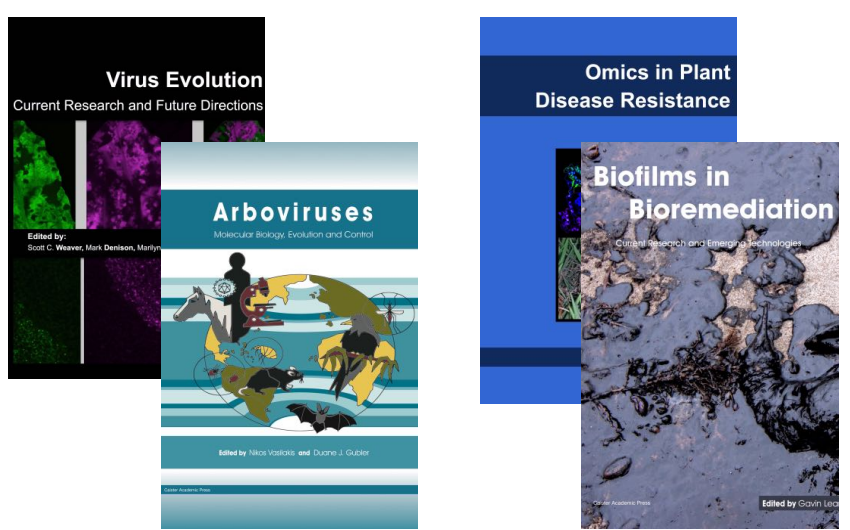
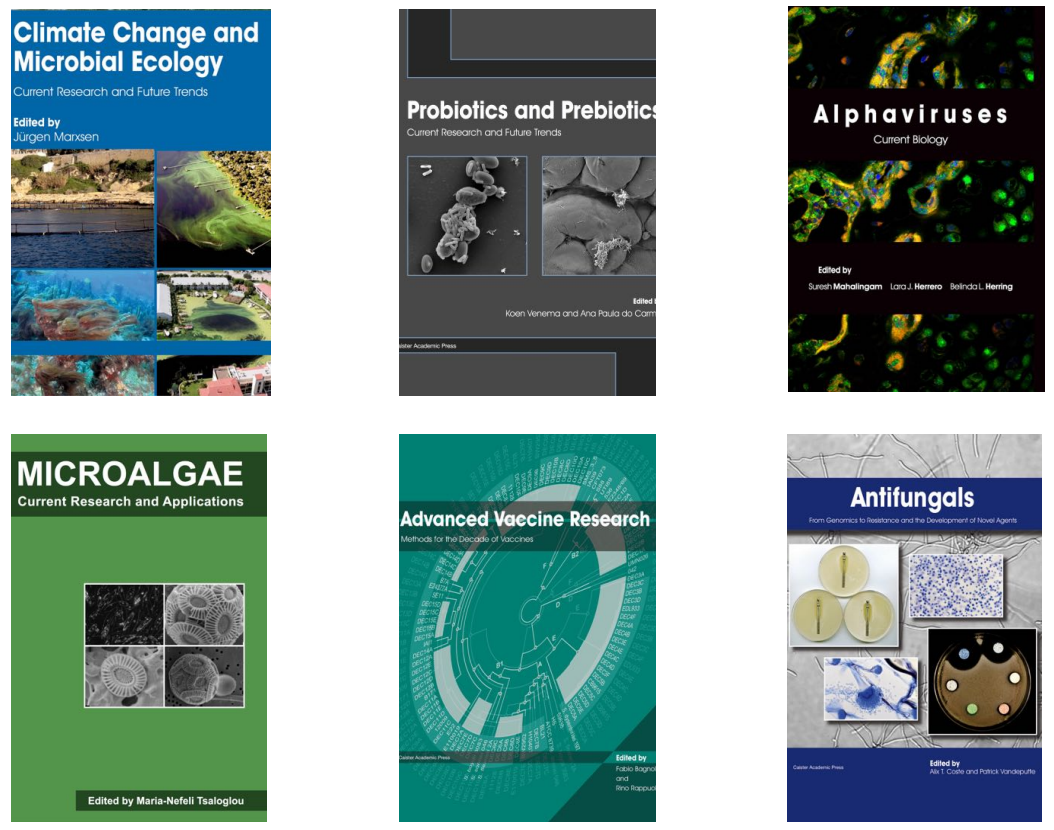

- Flow Cytometry in Microbiology: Technology and Applications Edited by: MG Wilkinson (2015) www.caister.com/flow

- Probiotics and Prebiotics: Current Research and Future Trends Edited by: K Venema, AP Carmo (2015) www.caister.com/probiotics

- Epigenetics: Current Research and Emerging Trends Edited by: BP Chadwick (2015) www.caister.com/epigenetics2015

- Corynebacterium glutamicum: From Systems Biology to Biotechnological Applications

Edited by: A Burkovski (2015)

www.caister.com/cory2

- Advanced Vaccine Research Methods for the Decade of Vaccines

Edited by: F Bagnoli, R Rappuoli (2015)

www.caister.com/vaccines

- Antifungals: From Genomics to Resistance and the Development of Novel Agents

Edited by: AT Coste, P Vandeputte (2015)

www.caister.com/antifungals

- Bacteria-Plant Interactions: Advanced Research and Future Trends Edited by: J Murillo, BA Vinatzer, RW Jackson, et al. (2015) www.caister.com/bacteria-plant

\section{- Aeromonas}

Edited by: J Graf (2015)

www.caister.com/aeromonas

- Antibiotics: Current Innovations and Future Trends

Edited by: S Sánchez, AL Demain (2015)

www.caister.com/antibiotics

- Leishmania: Current Biology and Contro Edited by: S Adak, R Datta (2015) www.caister.com/leish2

- Acanthamoeba: Biology and Pathogenesis (2nd edition) Author: NA Khan (2015)

www.caister.com/acanthamoeba2

- Microarrays: Current Technology, Innovations and Applications Edited by: Z He (2014)

www.caister.com/microarrays2

- Metagenomics of the Microbial Nitrogen Cycle: Theory, Methods and Applications

Edited by: D Marco (2014)

www.caister.com/n2 